\title{
Raynaud's phenomenon in limited cutaneous systemic sclerosis
}

\author{
Alex K Bonnecaze
}

Department of Internal Medicine, Wake Forest School of Medicine, Winston-Salem, North Carolina, USA

\section{Correspondence to}

Dr Alex K Bonnecaze, abonneca@wakehealth.edu

Accepted 12 December 2015

\section{DESCRIPTION}

A 41-year-old African American woman with no significant medical history presented to clinic reporting of episodic finger numbness and colour changes. She described feeling as if her fingers were frostbitten and noted her second, third and fourth digits appeared white distally. She additionally reported of occasionally feeling food stuck in her throat after consuming solids. Physical examination revealed no joint abnormalities or evidence of skin tightening. Laboratories revealed a creatinine level of $0.95 \mathrm{mg} / \mathrm{dL}$ and trace proteinuria. An antinuclear antibody test was positive at 1:1200 and anticentromere antibody was also positive. The diagnosis of limited cutaneous systemic sclerosis (lcSSc) was performed on the basis of the patient's symptoms and aforementioned serology. Her dysphagia was concerning for oesophageal dysmotility and required gastroenterology follow-up.

The above images highlight one of the patient's episodes of Raynaud's phenomenon (RP) (figures 1 and 2). The patient reported this as having occurred several times per week over the past 18 months and was unable to associate it with any precipitating or alleviating factors. The patient was scheduled to follow-up further with rheumatology for management and monitoring of lcSSc.

In RP, cold and pale fingertips result from episodic peripheral vasospasm. Nailfold capillaroscopy is often used to differentiate primary versus secondary RP, with decreased or distorted capillary loops being highly specific for secondary RP. ${ }^{1}$ While a wide variety of treatment modalities exist, current evidence supports the use of calcium channel blockers such as amlodipine or nifedipine, PDE-5 inhibitors, and prostanoids such as iloprost and beraprost sodium. $^{2}$

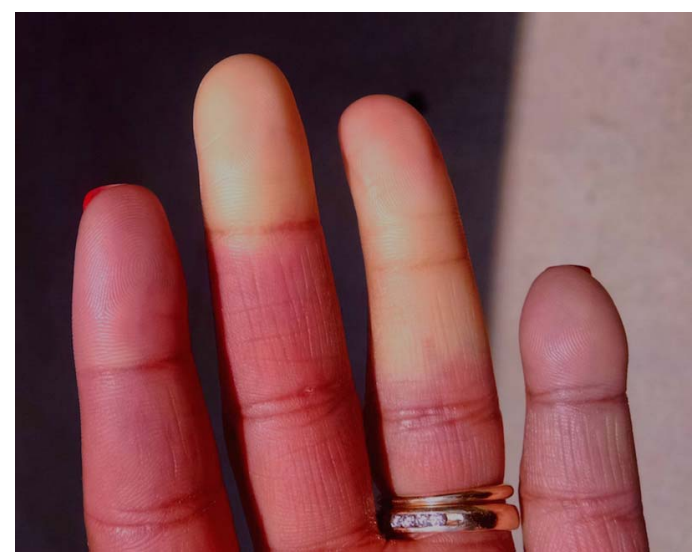

Figure 1 Left hand during onset of Raynaud's phenomenon episode.

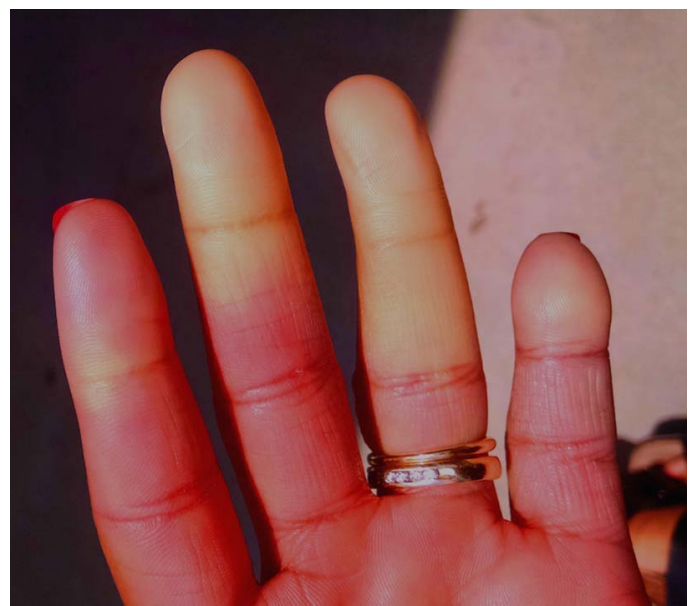

Figure 2 Left hand 30 min into a Raynaud's phenomenon episode.

\section{Learning points}

- Raynaud's phenomenon (RP) features a triphasic colour response as fingertips change colour in response to perfusion changes. Initial vasospasm results in pale white fingertips, followed by blue discolouration secondary to circulatory stasis, and, finally, red appearance in the setting of reperfusion. Work up should include thorough history-taking and screening for rheumatological disease.

- Nailfold capillaroscopy is an effective diagnostic method for differentiating primary from secondary RP, with secondary RP typically exhibiting capillary distortion and (or) loss.

- While primary RP occurs without associated disease and is classically a benign condition, secondary RP is associated with a wide variety of diseases including scleroderma, systemic lupus erythaematous and other autoimmune diseases, cryoglobulinaemia, hypothyroidism, sympathomimetic drug use and paraneoplastic syndrome.

- Current evidence most strongly supports calcium channel blockers, PDE-5 inhibitors, and prostacyclins such as beraprost sodium and iloprost, for symptomatic control of RP.

Competing interests None declared.

Patient consent Obtained.

Provenance and peer review Not commissioned; externally peer reviewed. 


\section{REFERENCES}

1 Ingegnoli F, Boracchi P, Gualtierotti R, et al. Prognostic model based on nailfold capillaroscopy for identifying Raynaud's phenomenon patients at high risk for the development of a scleroderma spectrum disorder: PRINCE (prognostic index for nailfold capillaroscopic examination). Arthritis Rheum 2008;58:2174-82.
2 Cappelli L, Wigley FM. Management of Raynaud phenomenon and digital ulcers in scleroderma. Rheum Dis Clin North Am 2015; 41:419-38.

Copyright 2015 BMJ Publishing Group. All rights reserved. For permission to reuse any of this content visit http://group.bmj.com/group/rights-licensing/permissions.

BMJ Case Report Fellows may re-use this article for personal use and teaching without any further permission.

Become a Fellow of BMJ Case Reports today and you can:

- Submit as many cases as you like

- Enjoy fast sympathetic peer review and rapid publication of accepted articles

- Access all the published articles

- Re-use any of the published material for personal use and teaching without further permission

For information on Institutional Fellowships contact consortiasales@bmjgroup.com

Visit casereports.bmj.com for more articles like this and to become a Fellow 